11. Harlan JM, Callahan KS 1984 Role of hydrogen peroxide in the neutrophil mediated release of prostacyclin from cultured endothelial cells. J Clin Invest 74:442-448

12. Winn R, Harlan J, Nadir B, Harker L, Hildebrandt J 1983 Thromboxane A mediates lung vasoconstriction but not permeability after endotoxin. J Clin Invest $72: 911-918$

13. Zar JH 1974 Biostatistical Analysis. Prentice Hall, Englewood Cliffs, NJ, pp $105-114$

14. Rojas J, Palme C, Ogletree, ML, Hellerquist CG, Brigham KL, Stahlman MT 1984 Effects of methylprednisolone on the response to group B streptococcal toxin in sheep. Pediatr Res 18:1141-1144

15. Harlan J, Winn R, Hildebrandt J, Harker L 1983 Selective inhibition of thromboxane synthesis during experimental endotoxemia in the goat: effects on pulmonary haemodynamics and lung lymph flow. Br J Clin Pharmacol 15:123S-126S

16. Farrukh IS, Michael JR, Summer WR, Adkinson NF, Gurtner GH 1985 Thromboxane-induced pulmonary vasoconstriction: involvement of calcium. J Appl Physiol 58:34-44

17. Parry MJ, Randall MJ, Hawkesford E, Cross PE, Dickinson RP 1982 Enhanced production of prostacyclin in blood after treatment with selective thromboxane synthetase inhibitor UK 38,485. Br J Pharmacol 77:547(abstr)

18. Piper P, Temple D 1981 Effect of lipoxygenase inhibitors and diethylcarbamazine on the immunological release of slow reacting substance of anaphylaxis from guinea pig chopped lung. J Pharm. Pharmacol 33:384-386

19. Hanna CJ, Bach MK, Pare PD 1981 Slow reacting substances (leukotrines) contract human airway and pulmonary vascular smooth muscle in vitro. Nature 290:343-344

20. Colley P, Cheney F, Hlastala M 1979 Ventilation-perfusion and gas exchange effects of sodium nitroprusside in sheep with normal and edematous lungs. Anesthesiology 50:489

21. Dantzker DR, Bower JS 1981 Pulmonary vascular tone improves $\dot{V}_{A} / \dot{Q}$ matching in obliterative pulmonary hypertension. J Appl Physiol 51:607613

22. Truog WE, Standaert TA 1984 Effect of dopamine infusion on pulmonary gas exchange in lambs. Biol Neonate 46:220-228

23. Short BL, Miller MK, Fletcher JR 1982 Improved survival in the suckling rat model of GBS sepsis after treatment with non-steroidal anti inflammatory drugs. Pediatrics 70:343-348

\title{
Announcement
}

\section{Amino Acids in Health and Disease}

A Searle-UCLA Symposium, organized by Drs. John Fernstrom, Jack Filer, Seymour Kaufman, Robert Roth, Lewis Stegink and Savio Woo will be presented May 30 to June 4, 1986 in Keystone, CO. A multi-disciplinary meeting to examine new research on amino acid transport, metabolism, and function; a heavy emphasis will be placed on amino acids acting on the brain. Major sessions will be held on Amino Acid Transport (chaired by H. Christensen, University of Michigan); Hydroxylases (chaired by S. Kaufman, NIMH); Neurotransmitter Regulation: Behavior and Function: Appetite; Behavior and Function: Blood Pressure; and Disease States: The PKU Paradigm (chaired by S. Woo, Baylor College of Medicine). Informal workshops will be held on Pathophysiology of Amino Acid Transport; Regulation of Hydroxylases; Neurotransmitters and Behavior; and Molecular Genetics. Conference fee: \$132; CME credit will be available. Contact UCLA Symposia, Molecular Biology Institute, University of California, Los Angeles, CA 90024; (213) 206-6292. 